\title{
Colorant Application Volume and Color Persistence on a 'Chisholm' Zoysiagrass Lawn
}

\author{
Ross Braun ${ }^{1,3}$, Jack Fry ${ }^{1}$, Megan Kennelly ${ }^{2}$, Dale Bremer ${ }^{1}$, \\ and Jason Griffin ${ }^{1}$
}

AdDITIONAL INDEX WORDs. paint, turfgrass, winter color, dormancy, turf colorant

SUMMARY. Zoysiagrass (Zoysia sp.) is a warm-season turfgrass that requires less water and fewer cultural inputs than cool-season grasses, but its widespread use by homeowners in the transition zone may be limited because of its extended duration of brown color during dormancy. Turf colorants are an option for improving zoysiagrass winter color. Our objective was to quantify the impact of colorants applied in autumn at three application volumes on persistence of green color on lawn-height 'Chisholm' zoysiagrass (Zoysia japonica). The commercial colorants Green Lawnger, Endurant, and Wintergreen Plus were applied in Oct. 2013 in Manhattan, KS, and Haysville, KS, in solutions with water at 80, 160, or $240 \mathrm{gal} / \mathrm{acre}$ at a 1:6 dilution (colorant:water) and evaluated through late 2013 and Spring 2014. Tall fescue (Festuca arundinacea), a cool-season turfgrass commonly used in home lawns in the transition zone, was included for comparison. Persistence of green color increased with application volume, but differences among colorants were limited. Colorants provided acceptable color (i.e., a visual rating $\geq 6$ on a 1 to 9 scale) for 55 to 69 days at $80 \mathrm{gal} / \mathrm{acre}, 69$ to 118 days at $160 \mathrm{gal} / \mathrm{acre}$, and 118 to 167 days at $240 \mathrm{gal} / \mathrm{acre}$. Compared with tall fescue, colorant-treated zoysiagrass had significantly higher color ratings for 98 to 112 days at $80 \mathrm{gal} / \mathrm{acre}, 112$ to 154 days at $160 \mathrm{gal} / \mathrm{acre}$, and 138 to 154 days at $240 \mathrm{gal} / \mathrm{acre}$. Colorants increased turfgrass canopy temperature by up to $12.1^{\circ} \mathrm{F}$, but did not accelerate spring greenup. Duration of acceptable color on 'Chisholm' zoysiagrass lawns can be enhanced by increasing colorant application volume.

$\mathrm{W}$ ater is a limited resource and its use to irrigate landscapes is under increasing scrutiny. Warm-season turfgrasses, including zoysiagrass, are more heat and drought resistant than cool-season grasses, which results in water savings (Fry and Huang, 2004). In the transition zone, where both cool- and warm-season grasses are options, zoysiagrass requires fewer inputs of pesticides and fertilizers than most cool-season turfgrass species (Fry et al., 2008). However, in the transition zone, one perceived benefit of cool-season turfgrasses is that they remain green late into autumn and also green-up early in the spring. In

We appreciate the funding provided by the Heart of America Golf Course Superintendents Association, Kansas Golf Course Superintendents Association, and Kansas Turfgrass Foundation in support of this project. We thanks Tim Todd, consulting statistician, for his assistance with data analysis. Colorant information and assistance provided by Grady Miller, Don Spier, and Jennifer Seevers were greatly appreciated. Contribution number 15-420-J of the Kansas Agricultural Experiment Station.

${ }^{1}$ Department of Horticulture, Forestry and Recreation Resources, Kansas State University, Manhattan, KS 66506

${ }^{2}$ Department of Plant Pathology, Kansas State University, Manhattan, KS 66506

${ }^{3}$ Corresponding author. E-mail: rossbraun@ksu.edu. contrast, zoysiagrass turns brown following the first autumn frost and remains dormant until mid to late spring. Some homeowners in the transition zone may avoid use of zoysiagrass because they object to its long duration of brown color during dormancy.

'Chisholm' zoysiagrass is a suitable turfgrass for residential and commercial lawns, parks, and golf courses in the transition zone (Chandra et al., 2014). In Kansas, 'Chisholm' usually takes on a straw-brown color of dormancy in October and begins to greenup in mid to late April as noted in studies during its development when it was evaluated under the experimental designation DALZ0102 (Okeyo et al., 2011). The dormancy period can be unappealing to homeowners, especially when cool-season grasses, which retain color longer in autumn and green-up sooner in spring, are grown in the same vicinity.

Turf colorants are an option for improving zoysiagrass color during dormancy. The use of turf colorants has become popular on golf course fairways and putting greens in the southern United States to provide green color during winter dormancy (Long, 2006). The turf colorants Titan Green Turf (Burnett Athletics, Campobello, SC), Green Lawnger (BASF Corp., Florham Park, NJ), and Regreen (Precision Laboratories, Waukegan, IL) provided acceptable turf quality on a 'TifEagle' hybrid bermudagrass (Cynodon dactylon $\times$ C. transvaalensis) putting green during the winter in South Carolina when applied in a dilution of 1:10 (colorant: water) at a rate of $283 \mathrm{gal} / \mathrm{acre}$ (Liu et al., 2007). The turf colorants Wintergreen Plus (Precision Laboratories) and Turf in a Bottle (US Specialty Coatings, Norcross, GA) applied once in autumn in a dilution of $1: 10$ (colorant: water) at rate of $80 \mathrm{gal} /$ acre enhanced winter color of 'Diamond' zoysiagrass (Zoysia matrella) and 'Miniverde' hybrid bermudagrass putting greens (Briscoe et al., 2010).

Colorant application volume has been shown to affect turf color and duration. In North Carolina, intensity of visual turf color increased from $1 \%$ to $44 \%$ on 'Miniverde' hybrid bermudagrass and $11 \%$ to $15 \%$ on 'Diamond' zoysiagrass putting greens when application volumes increased from 80 to $160 \mathrm{gal} / \mathrm{acre}$ (Briscoe et al., 2010). Briscoe et al. (2010) reported a variety of turf colorants provided acceptable visual turf color up to at least $56 \mathrm{~d}$ after treatment at a rate of $80 \mathrm{gal} /$ acre in $1: 7$ or $1: 10$ (colorant:water) dilutions on zoysiagrass mowed at golf course green height. It was also reported that there was an unspecified increase in the longevity of acceptable visual turf color for treated zoysiagrass greens with colorants Green

\begin{tabular}{llll}
\hline $\begin{array}{l}\text { Units } \\
\text { To convert U.S. to SI, } \\
\text { multiply by }\end{array}$ & U.S. unit & SI unit & $\begin{array}{l}\text { To convert SI to U.S., } \\
\text { multiply by }\end{array}$ \\
\hline 0.3048 & $\mathrm{ft}$ & $\mathrm{m}$ & 3.2808 \\
3.7854 & $\mathrm{gal}$ & $\mathrm{L}$ & 0.2642 \\
9.3540 & gal $/ \mathrm{acre}$ & $\mathrm{L} \cdot \mathrm{ha}^{-1}$ & 0.1069 \\
2.54 & inch $(\mathrm{es})$ & $\mathrm{cm}$ & 0.3937 \\
48.8243 & lb $/ 1000 \mathrm{ft}^{2}$ & $\mathrm{~kg} \cdot \mathrm{ha}^{-1}$ & 0.0205 \\
1.6093 & $\mathrm{mph}$ & $\mathrm{km} \cdot \mathrm{h}^{-1}$ & 0.6214 \\
$\left({ }^{\circ} \mathrm{F}-32\right) \div 1.8$ & ${ }^{\circ} \mathrm{F}$ & ${ }^{\circ} \mathrm{C}$ & $\left({ }^{\circ} \mathrm{C} \times 1.8\right)+32$
\end{tabular}


Lawnger, Turf in a Bottle, and Ultradwarf Super (Pioneer Athletics, Cleveland, $\mathrm{OH}$ ) applied at a rate of $160 \mathrm{gal} /$ acre (Briscoe et al., 2010). However, information is lacking on effects of colorants and application volumes on zoysiagrass maintained at the higher mowing heights used on home lawns and golf course roughs. Therefore, our objective was to quantify the impact of colorants applied in autumn at three application volumes on persistence of green color on lawnheight 'Chisholm' zoysiagrass.

\section{Materials and methods}

STUDY SITES AND TREATMENTS. Experiments were conducted at the Rocky Ford Turfgrass Research Center in Manhattan, KS, and the John C. Pair Horticultural Center in Haysville, KS. Turf was 'Chisholm' zoysiagrass maintained at a 2.5 -inch height. No mowing occurred on zoysiagrass during the study due to winter dormancy. Soil at Manhattan was a Chase silt loam; at Haysville, soil was a Canadian-Waldeck fine sandy loam. Zoysiagrass at both locations received a June application $1 \mathrm{lb} / 1000 \mathrm{ft}^{2} \mathrm{ni}^{-}$ trogen from urea $(46 \mathrm{~N}-0 \mathrm{P}-0 \mathrm{~K})$.

Plots measuring $5 \times 8 \mathrm{ft}$ were arranged in a randomized complete block design with three replicates. Treatments were 1) untreated, 2) Green Lawnger applied at a spray volume of 80 gal/acre, 3) Endurant (Geoponics Corp, Naples, FL) applied at $80 \mathrm{gal} /$ acre, 4) Wintergreen Plus applied at 80 gal/acre, 5) Green Lawnger applied at $160 \mathrm{gal} /$ acre, 6) Endurant applied at $160 \mathrm{gal} /$ acre, 7) Wintergreen Plus applied at $160 \mathrm{gal} / \mathrm{acre}, 8)$ Green Lawnger applied at $240 \mathrm{gal} / \mathrm{acre}, 9)$ Endurant applied at $240 \mathrm{gal} / \mathrm{acre}, 10)$ Wintergreen Plus applied at $240 \mathrm{gal} / \mathrm{acre}$, and 11) an established blend of tall fescue. Plots of tall fescue equivalent in size to those used to evaluate colorants were randomly assigned in three replicates in an area adjacent to the 'Chisholm' study area.

Colorants were applied using a one-nozzle, 3-gal rechargeable electric backpack sprayer (ProPack ${ }^{\mathrm{TM}}$ model SRS 600; SHURflo, Cypress, CA) with an adjustable cone nozzle calibrated to deliver $0.29 \mathrm{gal} / \mathrm{min}$. Turf colorants were applied at a dilution of 1:6 (colorant:water) to 'Chisholm' zoysiagrass with $15 \%$ to $20 \%$ green turf color remaining based on visual evaluation on 11 Oct. 2013 at Manhattan and on 24 Oct. 2013 with $10 \%$ to $15 \%$ green turf color remaining at Haysville. Wind speeds during application were 3 to $8 \mathrm{mph}$ at Manhattan and 10 to $15 \mathrm{mph}$ at Haysville. Tall fescue was an unknown blend of turf-type cultivars that was not treated with colorants.

DATA COLLECTION AND ANALYSIS. Visual turf color was rated every other week at Manhattan and monthly from 24 Oct. to 8 Apr. thereafter every other week at Haysville on a 1 to 9 scale where $1=$ straw brown, $6=$ acceptable green color for a home lawn, and $9=$ dark green (Morris and Shearman, 1999). For purposes of presentation, average monthly color ratings from 10 of 15 rating dates at Manhattan (Table 1) and 9 of 10 rating dates at Haysville (Table 2) are presented. Pantone color chips (Pantone LLC, 2015) were assigned $1 \mathrm{~d}$ after the first application for the 240 -gal/acre rate of each colorant.

Number of days of acceptable color for each treatment was determined using visual ratings and regression analysis. The rating date when visual color first dropped below a score of 6 was recorded and days since application determined. To determine days of acceptable turf color for each application volume nested within $\mathrm{col}^{-}$ orant, a linear regression equation was derived for turf visual color vs. time using REG procedure in SAS (version 9.2; SAS Institute, Cary, NC). Subsequently, a visual color score of 5.9 ( $y$ value) was inserted into the equation to determine the days $(x)$ that passed before that value was reached.

Starting 11 Mar. 2014, then every other week, soil temperatures at both sites at a 2 -inch depth were measured and averaged from three measurements within each plot between 1300 and 1500 HR on cloudless days using a digital T-bar thermometer (Argus Realcold, Coopers Plains, Australia). On the same date (11 Mar.), canopy temperatures at both sites were measured, and averaged, from three locations per plot between 1300 and $1500 \mathrm{HR}$ on cloudless days using a handheld infrared thermometer at a 4 -ft height above the canopy (model 100.3ZL; Everest Interscience, Tucson, AZ). Spring green-up of zoysiagrass was measured by visually inspecting new turf growth extending above the turf canopy, along with turf color ratings by investigators during late April/May rating dates.
Residual normality was tested with the $w$ statistic of the ShapiroWilk test using the UNIVARIATE procedure of SAS (version 9.2) (Shapiro and Wilk, 1965). Data were subjected to a 2 -fold nested analysis of variance using the GLIMMIX procedure of SAS 9.2 due to the fact of three application volumes nested within each colorant and only one "application volume" of tall fescue and untreated zoysiagrass was included. Factors were application volume nested within colorant and colorant. Treatment differences were separated using Fisher's protected least significant difference test $(P \leq 0.05)$. A homogeneity of variance test for location by treatment effect was significant for the study sites; therefore, results will be presented separately for each site. Data were also subjected to linear regression using the REG procedure in SAS (version 9.2).

\section{Results and discussion}

Turf COLOR. Color of 'Chisholm' zoysiagrass after application of Green Lawnger and Endurant was dark green, whereas that treated with Wintergreen Plus was blue green (Fig. 1). Pantone Color chips $357 \mathrm{C}$ for Green Lawnger, $2266 \mathrm{C}$ for Endurant, and 3295 C for Wintergreen Plus were assigned as the representative Pantone matching system for each colorant applied at a rate of $240 \mathrm{gal} /$ acre on lawn-height 'Chisholm' zoysiagrass at $1 \mathrm{~d}$; lower application volumes resulted in a less intense, brighter representative color (Pantone LLC, 2015). Some turf managers may prefer one color to another, but our color ratings reflected the intensity of the color, and we did not consider the hue of green in visual ratings.

The effect of spray volume nested within colorants was significant; therefore, each spray volume within each colorant was evaluated across all 11 treatments (Tables 1 and 2). Representative examples of change in visual appearance of colorant-treated 'Chisholm' are shown in Fig. 1 ( $1 \mathrm{~d})$ and Fig. 2 (118 d). In general, duration of acceptable turf color at each location increased with increasing application volume, and color ratings at each application volume decreased over time (Tables 1-3). All colorant-treated zoysiagrass had superior color compared with untreated zoysiagrass for a total of $197 \mathrm{~d}$ in Manhattan [11 Oct. to 25 Apr. (Table 1)] and 141 to $181 \mathrm{~d}$ in 
Table 1. Effect of colorant and application volume on color of 'Chisholm' zoysiagrass at the Rocky Ford Turfgrass Research Center, Manhattan, KS, in 2013-14.

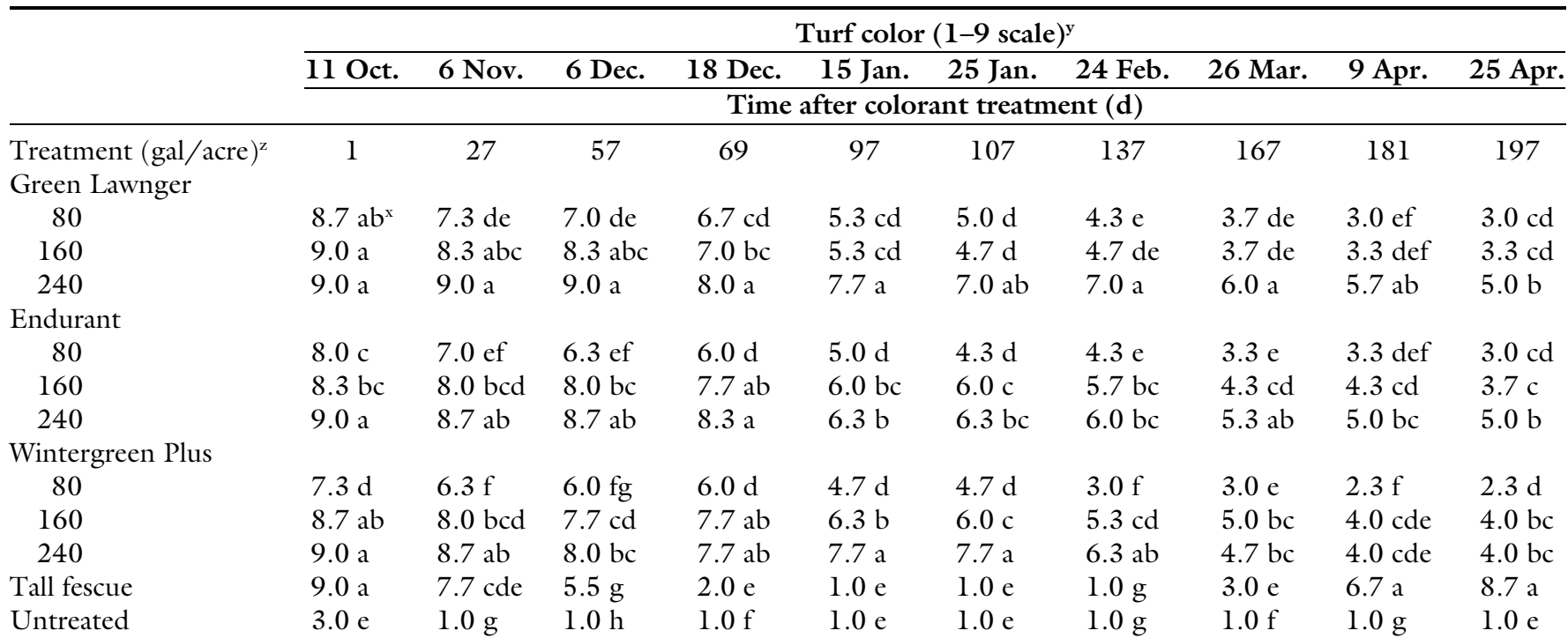

${ }^{\mathrm{z} G r e e n ~ L a w n g e r, ~ E n d u r a n t, ~ a n d ~ W i n t e r g r e e n ~ P l u s ~ w e r e ~ a p p l i e d ~ o n ~} 11$ Oct. 2013 at a dilution of 1:6 (colorant:water) using a one-nozzle, 3-gal (11.4 L) rechargeable electric backpack sprayer with an adjustable cone nozzle calibrated to deliver 0.29 gal $(1.098 \mathrm{~L})$ per minute; 1 gal $/ \mathrm{acre}^{2} 9.3540 \mathrm{~L} \cdot \mathrm{ha}^{-1}$.

'Turf color was rated visually on a 1 to 9 scale where $1=$ straw brown, $6=$ acceptable green color (light green), and $9=$ dark green.

${ }^{x}$ Means in a column followed by the same letter are not significantly different according Fisher's protected least significant difference test $(P \leq 0.05)$.

Table 2. Effect of colorant and application volume on color of 'Chisholm' zoysiagrass at the John C. Pair Horticultural Center, Haysville, KS, in 2013-14.

\begin{tabular}{|c|c|c|c|c|c|c|c|c|c|}
\hline & \multicolumn{9}{|c|}{ Turf color ( $1-9$ scale $)^{y}$} \\
\hline & 24 Oct. & 21 Nov. & 17 Dec. & 17 Jan. & 18 Feb. & 13 Mar. & 8 Apr. & 22 Apr. & 6 May \\
\hline & \multicolumn{9}{|c|}{ Time after colorant treatment $(\mathrm{d})$} \\
\hline \multicolumn{10}{|l|}{ Green Lawnger } \\
\hline 80 & $6.7 \mathrm{~cd}^{\mathrm{x}}$ & $6.7 \mathrm{ef}$ & $6.7 \mathrm{c}$ & $3.7 \mathrm{de}$ & $3.0 \mathrm{~cd}$ & 3.0 ef & $2.3 \mathrm{def}$ & $2.7 \mathrm{e}$ & 4.7 \\
\hline 160 & $8.0 \mathrm{~b}$ & $8.0 \mathrm{bc}$ & $8.0 \mathrm{ab}$ & $6.3 \mathrm{bc}$ & $4.7 \mathrm{~b}$ & $4.0 \mathrm{cde}$ & $3.7 \mathrm{~cd}$ & $4.3 \mathrm{~cd}$ & 5.3 \\
\hline 80 & $6.3 \mathrm{~d}$ & $6.3 \mathrm{f}$ & $6.0 \mathrm{c}$ & $3.3 \mathrm{e}$ & $2.7 \mathrm{~d}$ & $2.3 \mathrm{f}$ & $2.0 \mathrm{ef}$ & $2.3 \mathrm{e}$ & 4.0 \\
\hline 160 & $7.7 \mathrm{~b}$ & 7.3 cde & $7.0 \mathrm{bc}$ & $6.0 \mathrm{c}$ & $4.7 \mathrm{~b}$ & $3.7 \mathrm{de}$ & $3.0 \mathrm{cde}$ & $3.3 \mathrm{de}$ & 4.7 \\
\hline 240 & $9.0 \mathrm{a}$ & $9.0 \mathrm{a}$ & $8.7 \mathrm{a}$ & $6.7 \mathrm{bc}$ & $6.0 \mathrm{a}$ & $4.7 \mathrm{~cd}$ & $4.3 \mathrm{bc}$ & $4.3 \mathrm{~cd}$ & 4.7 \\
\hline \multicolumn{10}{|l|}{ Wintergreen Plus } \\
\hline 80 & $7.0 \mathrm{c}$ & $7.0 \mathrm{def}$ & $6.3 c$ & $4.7 \mathrm{~d}$ & $3.7 \mathrm{c}$ & 3.3 ef & $2.7 \mathrm{de}$ & $2.3 \mathrm{e}$ & 5.0 \\
\hline
\end{tabular}

${ }^{\mathrm{z}}$ Green Lawnger, Endurant, and Wintergreen Plus were applied on 24 Oct. 2013 at a dilution of 1:6 (colorant:water) using a one nozzle, 3-gal (11.4 L) rechargeable electric backpack sprayer with an adjustable cone nozzle calibrated to deliver $0.29 \mathrm{gal}(1.098 \mathrm{~L})$ per minute; $1 \mathrm{gal} / \mathrm{acre}=9.3540 \mathrm{~L} \cdot \mathrm{ha}^{-1}$.

'Turf color was rated visually on a 1 to 9 scale where $1=$ straw brown, $6=$ acceptable green color (light green), and $9=$ dark green.

${ }^{x}$ Means in a column followed by the same letter are not significantly different according Fisher's protected least significant difference test $(P \leq 0.05)$. Lack of letters indicates no significant differences $(P>0.05)$ on that date.

Haysville [24 Oct. to 13 Mar./22 Apr. (Table 2)].

Differences in color ratings based on the application volumes of 160 vs. $80 \mathrm{gal} / \mathrm{acre}$ for all three colorant products were evident at Manhattan at $27 \mathrm{~d}$ and at Haysville at $29 \mathrm{~d}$ after treatment (Tables 1 and $2)$. Across all three colorant products at 27 and $29 \mathrm{~d}$, turf color was $14 \%$ to $27 \%$ higher in turf treated at 160 compared with $80 \mathrm{gal} / \mathrm{acre}, 3 \%$ to $23 \%$ higher in turf treated at 240 compared with $160 \mathrm{gal} / \mathrm{acre}$, and $23 \%$ to $43 \%$ higher in turf treated at 240 compared with $80 \mathrm{gal} / \mathrm{acre}$. The same volume-dependent effect on color occurred throughout the experiments in Manhattan and Haysville. The enhanced color on 'Chisholm' zoysiagrass that we observed with increasing colorant application volume was similar to the findings of Briscoe et al. (2010) who evaluated increasing colorant application volume on 'Diamond' zoysiagrass putting greens in North Carolina. In that experiment, turf color $35 \mathrm{~d}$ after treatment was $11 \%$ to $15 \%$ greater when the colorants Green Lawnger, Turf in a Bottle, and Ultradwarf Super were applied at 160 compared with $80 \mathrm{gal} /$ acre (Briscoe et al., 2010). 


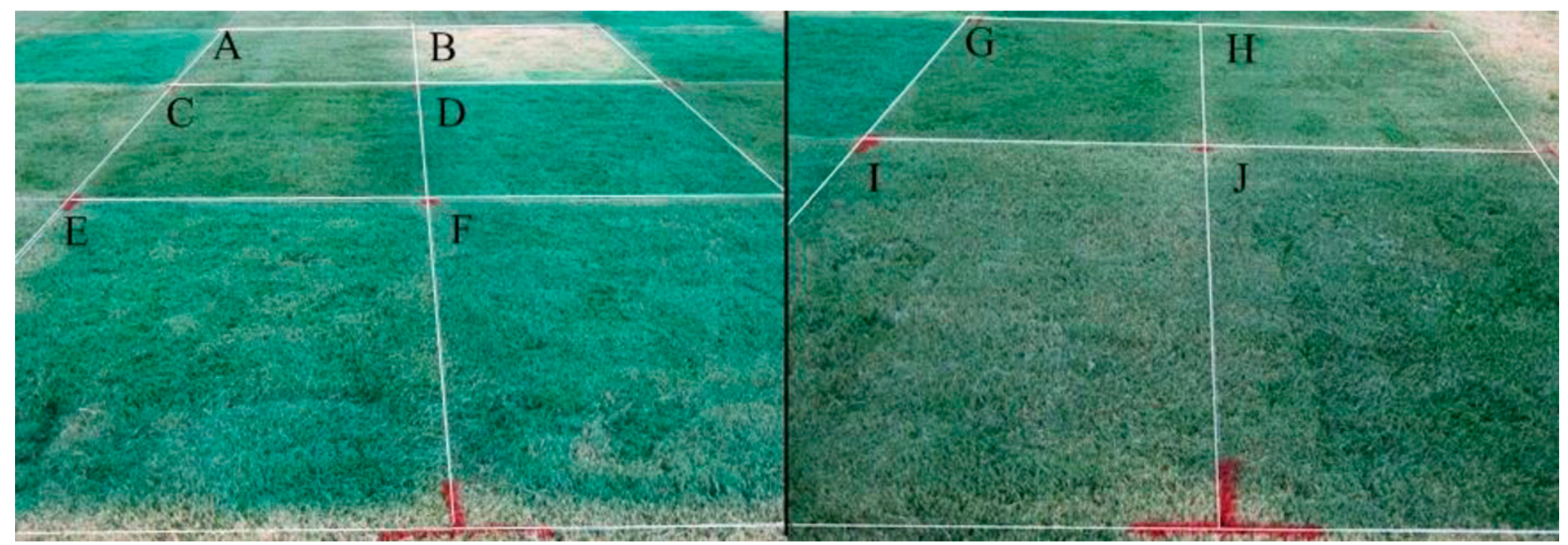

Fig. 1. 'Chisholm' zoysiagrass experimental area at the Rocky Ford Turfgrass Research Center, Manhattan, KS, on 11 Oct. 2013 (1 d): (A) Green Lawnger at 160 gal/acre, (B) untreated, (C) Endurant at 240 gal/acre, (D) Wintergreen Plus at $240 \mathrm{gal} / \mathrm{acre},(\mathrm{E})$ Wintergreen Plus at $80 \mathrm{gal} / \mathrm{acre}$, (F) Wintergreen Plus at $160 \mathrm{gal} / \mathrm{acre},(\mathrm{G})$ Endurant at $160 \mathrm{gal} / \mathrm{acre},(\mathrm{H})$ Endurant at $80 \mathrm{gal} / \mathrm{acre},(\mathrm{I}) \mathrm{Green} \mathrm{Lawnger} \mathrm{at} 80 \mathrm{gal} / \mathrm{acre}$, and (J) Green Lawnger at $240 \mathrm{gal} / \mathrm{acre}^{1} \mathrm{gal} / \mathrm{acre}=9.3540 \mathrm{~L} \cdot \mathrm{ha}^{-1}$.

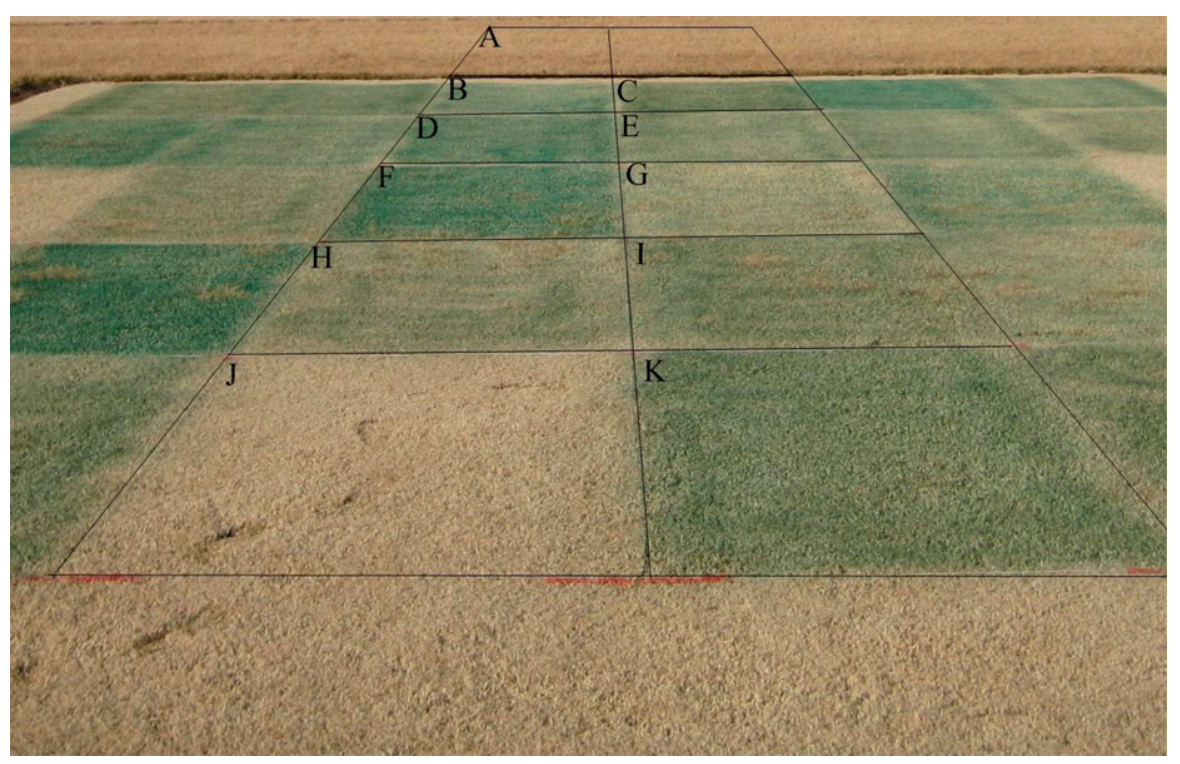

Fig. 2. Chisholm zoysiagrass experimental area on $18 \mathrm{Feb} .2014(118 \mathrm{~d})$ at the John C. Pair Horticultural Center, Haysville, KS: (A) 'K-31' tall fescue, (B) Wintergreen Plus at $80 \mathrm{gal} / \mathrm{acre}$, (C) Green Lawnger at $240 \mathrm{gal} / \mathrm{acre}$, (D) Wintergreen Plus at $160 \mathrm{gal} / \mathrm{acre}$, (E) Endurant at $160 \mathrm{gal} / \mathrm{acre}$, (F) Wintergreen Plus at $240 \mathrm{gal} / \mathrm{acre},(\mathrm{G})$ Endurant at $80 \mathrm{gal} / \mathrm{acre},(\mathrm{H})$ Green Lawnger at $80 \mathrm{gal} / \mathrm{acre},(\mathrm{I})$ Green Lawnger at $160 \mathrm{gal} / \mathrm{acre}$, (J) untreated, and (K) Endurant at $240 \mathrm{gal} / \mathrm{acre}$. Tall fescue in this image is a representative depiction of the tall fescue plot area that lay adjacent to the colorant study area; $1 \mathrm{gal} / \mathrm{acre}=9.3540 \mathrm{~L} \cdot \mathrm{ha}^{-1}$.

Tall fescue, a commonly used cool-season grass in Kansas, had better visual turf color than untreated 'Chisholm' zoysiagrass for a total of $112 \mathrm{~d}$ between 11 Oct. and 21 May (a 223-d period) in Manhattan and $83 \mathrm{~d}$ between 24 Oct. and 20 May (a 209-d period) in Haysville (Tables 1 and 2). However, tall fescue had a below-acceptable color rating for $124 \mathrm{~d}$ in Manhattan and $112 \mathrm{~d}$ in
Endurant in Haysville), 138 d (Wintergreen Plus in Haysville), $140 \mathrm{~d}$ (Green Lawnger in Manhattan), and $154 \mathrm{~d}$ (Endurant and Wintergreen Plus in Manhattan). All three colorant products applied at $240 \mathrm{gal} /$ acre provided turf with significantly better color than tall fescue for $154 \mathrm{~d}$ in Manhattan and $138 \mathrm{~d}$ in Haysville.

Colorants provided definitive differences in color intensity and duration of color for 80 vs. $240 \mathrm{gal} /$ acre, but differences between 160 vs. 240 gal/acre and 80 vs. $160 \mathrm{gal} /$ acre were generally less pronounced (Tables 1 and 2 ). Based on observed visual ratings across all colorants and locations, 'Chisholm' color was acceptable for an average of $62 \mathrm{~d}$ at $80 \mathrm{gal} / \mathrm{acre}, 96 \mathrm{~d}$ at $160 \mathrm{gal} / \mathrm{acre}$, and $140 \mathrm{~d}$ at $240 \mathrm{gal} /$ acre (Table 3 ). Predicted days of acceptable color determined using regression analysis generally mirrored those of visual ratings, with $R^{2}$ values ranging from 0.72 to 0.93 .

Both sites had a similar duration of zoysiagrass dormancy, however, there was less green zoysiagrass color remaining and a greater wind speed during colorant application at Haysville, which may have affected color intensity and duration compared with Manhattan. A higher amount of green turf color remaining and proper environmental conditions duration application could possibly influence color intensity and duration. Zoysiagrass dormancy periods vary by region and by variations in annual weather, and locations with shorter periods of dormancy 
may be able to maintain a sufficient duration of acceptable color with a lower application rate, such as 80 gal/acre. Multiple applications at lower rates are also an option and were evaluated by Braun (2014), but those results were not presented herein.

Temperature. Colorants influenced canopy (Table 4) but not soil (data not shown) temperatures. Neither the effect of application volume nested within colorant nor the main effect of colorant was significant for soil temperature at either site. The main effect of colorant was significant at both experiment locations; however, application volume nested within colorant effect was not significant for

Table 3. Days of acceptable green color of 'Chisholm' zoysiagrass based upon visual color ratings (observed) and regression analysis (predicted) at the Rocky Ford Turfgrass Research Center, Manhattan, KS, and John C. Pair Horticultural Center, Haysville, KS, in 2013-14.

\begin{tabular}{|c|c|c|c|c|}
\hline \multirow[b]{2}{*}{ Treatment (gal/acre) ${ }^{\mathrm{z}}$} & \multirow[b]{2}{*}{ Location $^{\mathrm{y}}$} & \multicolumn{2}{|c|}{$\begin{array}{c}\text { Duration of acceptable } \\
\text { green color }(\mathbf{d})\end{array}$} & \multirow[b]{2}{*}{$\mathbf{R}^{2 \mathrm{v}}$} \\
\hline & & Observed $^{\mathrm{x}}$ & Predicted $^{\mathrm{w}}$ & \\
\hline \multicolumn{5}{|l|}{ Green Lawnger } \\
\hline \multirow[t]{2}{*}{80} & M & 69 & 80 & 0.87 \\
\hline & $\mathrm{H}$ & 55 & 40 & 0.80 \\
\hline \multirow[t]{2}{*}{160} & M & 69 & 99 & 0.89 \\
\hline & $\mathrm{H}$ & 86 & 93 & 0.72 \\
\hline \multirow[t]{2}{*}{240} & M & 167 & 167 & 0.93 \\
\hline & $\mathrm{H}$ & 141 & 152 & 0.82 \\
\hline \multicolumn{5}{|l|}{ Endurant } \\
\hline \multirow[t]{2}{*}{80} & M & 69 & 65 & 0.91 \\
\hline & $\mathrm{H}$ & 55 & 28 & 0.79 \\
\hline \multirow[t]{2}{*}{160} & M & 107 & 116 & 0.86 \\
\hline & $\mathrm{H}$ & 86 & 74 & 0.90 \\
\hline \multirow[t]{2}{*}{240} & M & 137 & 141 & 0.90 \\
\hline & $\mathrm{H}$ & 118 & 117 & 0.92 \\
\hline \multicolumn{5}{|l|}{ Wintergreen Plus } \\
\hline \multirow[t]{2}{*}{80} & M & 69 & 50 & 0.91 \\
\hline & $\mathrm{H}$ & 55 & 50 & 0.92 \\
\hline \multirow[t]{2}{*}{160} & M & 107 & 115 & 0.93 \\
\hline & $\mathrm{H}$ & 118 & 114 & 0.87 \\
\hline \multirow[t]{2}{*}{240} & M & 137 & 132 & 0.86 \\
\hline & $\mathrm{H}$ & 141 & 150 & 0.86 \\
\hline
\end{tabular}

${ }^{2}$ Turf color was rated visually on a 1 to 9 scale where $\mathrm{l}=$ straw brown, $6=$ acceptable green color (light green), and $9=$ dark green. Green Lawnger, Endurant, and Wintergreen Plus were applied on 11 Oct. 2013 at a dilution of $1: 6$ (colorant:water) using a one nozzle, 3 -gal $(11.4 \mathrm{~L})$ rechargeable electric backpack sprayer with an adjustable cone nozzle calibrated to deliver $0.29 \mathrm{gal}(1.098 \mathrm{~L})$ per minute; $1 \mathrm{gal} / \mathrm{acre}=9.3540 \mathrm{~L} \cdot \mathrm{ha}^{-1}$.

${ }^{y} \mathrm{M}=$ Rocky Ford Turfgrass Research Center, Manhattan, KS; H = John C. Pair Horticultural Center, Haysville, KS. 'Observed number of days after application for colorant treatment to drop below acceptable color based on visual ratings.

wPredicted number of days after application for colorant treatment to drop below acceptable color based on regression analysis.

${ }^{v}$ Coefficient of determination for the regression analysis.

0.87

0.80

0.72

0.93

0.82

0.91

0.79

0.86

0.90

.92

9.91

0.92

.93

.87

86 Whitlark and Umeda, 2012). Buffalograss (Buchloe dactyloides) treated in December with Lesco Green (John Deere Landscapes, Alpharetta, GA) had soil temperatures up to $8.4^{\circ} \mathrm{F}$ higher at 2-inch depth, which resulted in spring green-up in turf color $14 \mathrm{~d}$ earlier than untreated turf in Nebraska (Shearman et al., 2005).

Table 4. Effect of colorant on canopy temperature of 'Chisholm' zoysiagrass at the Rocky Ford Turfgrass Research Center, Manhattan, KS, and the John C. Pair Horticultural Center, Haysville, KS, in 2014.

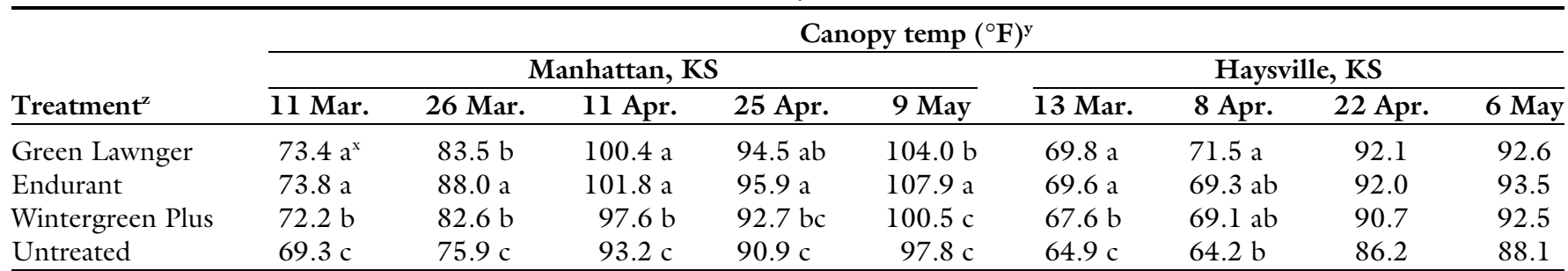

${ }^{\mathrm{z}}$ Green Lawnger, Endurant, and Wintergreen Plus were applied on 11 Oct. 2013 in Manhattan, KS, and 24 Oct. 2013 in Haysville, KS, at a dilution of 1:6 (colorant:water) using a one-nozzle, 3 -gal $(11.4 \mathrm{~L})$ rechargeable electric backpack sprayer with an adjustable cone nozzle calibrated to deliver 0.29 gal ( $1.098 \mathrm{~L})$ per minute. ${ }^{y}$ Canopy temperature was measured and averaged from three measurements within each plot using a handheld infrared thermometer; $\left({ }^{\circ} \mathrm{F}-32\right) \div 1.8={ }^{\circ} \mathrm{C}$.

${ }^{x}$ Means in a column followed by the same letter are not significantly different according Fisher's protected least significant difference test $(P \leq 0.05)$. Lack of letters indicates no significant differences $(P>0.05)$ on that date. 
In summary, Endurant, Green Lawnger, and Wintergreen Plus provided longer lasting acceptable visual color on 'Chisholm' zoysiagrass as volume increased from 80 to 240 $\mathrm{gal} / \mathrm{acre}$, averaging $62 \mathrm{~d}$ at $80 \mathrm{gal} / \mathrm{acre}$, $96 \mathrm{~d}$ at $160 \mathrm{gal} / \mathrm{acre}$, and $140 \mathrm{~d}$ at $240 \mathrm{gal} /$ acre. Some homeowners may be more amenable to the use of 'Chisholm', or other warm-season turfgrasses, if colorants are used to enhance the aesthetic appeal of dormant turf.

\section{Literature cited}

Braun, R. 2014. Cultural strategies to improve zoysiagrass acceptability and performance in the transition zone. MS Thesis, Kansas State Univ., Manhattan, NY.

Briscoe, K., G. Miller, and S. Brinton. 2010. Evaluation of green turf colorants as an alternative to overseeding on putting greens. Appl. Turfgrass Sci. doi:10.1094/ ATS-2010-0326-02-RS.

Chandra, A., J. Fry, M. Engelke, D. Genovesi, J. Reinert, M. Binzel, S. Metz, B. Wherley, Q. Zhang, and D. Okeyo.
2014. Registration of 'Chisholm' zoysiagrass. J. Plant Registrations 9:21-26.

Fry, J. and B. Huang. 2004. Applied turfgrass science and physiology. Wiley, Hoboken, NJ.

Fry, J., M. Kennelly, and R. St. John. 2008. Zoysiagrass: Economic and environmental sense in the transition zone. Golf Course Mgt. 76(5):127-132.

Liu, H., B.L. McCarty, C.M. Baldwin, W.G. Sarvis, and S.H. Long. 2007. Painting dormant bermudagrass putting greens. Golf Course Mgt. 75(11):86-91.

Long, S.H. 2006. Thatch control, winter painting, and plant regulator management on golf course putting greens. MS Thesis, Clemson Univ., Clemson, SC.

Morris, K.N. and R.C. Shearman. 1999. NTEP turfgrass evaluation guidelines. Natl. Turfgrass Evaluation Program, Beltsville, MD.

Okeyo, D.O., J.D. Fry, D. Bremer, C.B. Rajashekar, M. Kennelly, A. Chandra, D.A. Genovesi, and M.C. Engelke. 2011. Freezing tolerance and seasonal color of experimental zoysiagrass. Crop Sci. 51:2858-2863.

Pantone, LLC. 2015. Find a Pantone color. 1 Dec. 2015. <http://www.pantone. com/pages/pantone/colorfinder.aspx? $\mathrm{mm}>$.

Shapiro, S.S. and M.B. Wilk. 1965. An analysis of variance test for normality (complete samples). Biometrika 52:591-611.

Shearman, R.C., L.A. Wit, S. Severmutlu, H. Budak, and R.E. Gaussoin. 2005. Colorant effects on dormant buffalograss turf performance. Hort Technology 15: 244-246.

Whitlark, B. 2012. Ultradwarf bermudagrass tinting study: How do different paints and pigments affect the surface temperature of greens? USGA Green Section Record 50(3):1-6.

Whitlark, B. and K. Umeda. 2012. A New Hue: A guide to using colorants to enhance the color and growth of fine turfgrass in the southwestern U.S. USGA Green Section Record 50(20):1-2. 